\section{Prohexadione-calcium Inhibits Shoot Growth but Reduces the Efficacy of Gibberellin A4 + A7 in Suppressing 'Stayman' Apple Cracking}

\author{
Stephen S. Miller ${ }^{1}$
}

ADDITIONAL INDEX wORDs. Malus $\times$ domestica, skin disorder, plant growth regulator, plant bioregulator, shoot growth control, adjuvant, $\mathrm{GA}_{4+7}$, Apogee, ProVide

Summary. The 'Stayman' apple (Malus $\times$ domestica) is a high-quality apple with good fresh-fruit and processing characteristics. Trees are of moderate to high vigor where it is grown in large numbers in the mid-Atlantic region of the United States. However, 'Stayman' is prone to skin cracking, which in some seasons can result in losses that exceed $60 \%$ to $80 \%$ of the crop. A series of experiments was conducted between 1997 and 2001 to examine the effect of prohexadione-calcium (PCa) and a mixture of gibberellins A4 plus $\mathrm{A} 7\left(\mathrm{GA}_{4+7}\right)$ on shoot growth and cracking in 'Stayman 201' apple. PCa consistently reduced terminal shoot growth when applied in two or three sprays between petal fall (PF) and PF + 6 weeks [May and June (postbloom)]. PCa applied postbloom combined with three or four preharvest (July and August) PCa applications reduced the growth of water sprouts. The level of 'Stayman' fruit cracking varied with year, but in three of five experiments conducted from 1997 through 2001, five biweekly $\mathrm{GA}_{4+7}$ sprays applied alone preharvest reduced the percentage of cracked fruit at harvest. With only a few exceptions, spraying with PCa increased fruit cracking. When $\mathrm{GA}_{4+7}$ was applied to trees previously treated postbloom with $\mathrm{PCa}$, the percentage of cracked fruit was often reduced, but not always, and generally not to the same level as that in non-PCatreated trees. Fruit cracking was increased compared with the untreated control when a spray adjuvant was included with the postbloom PCa spray. PCa or $\mathrm{GA}_{4+7}$ had no effect on yield or fruit weight at harvest. The results of this study suggest caution in the use of PCa to suppress shoot growth in bearing 'Stayman' apple trees because of the potential for increased fruit cracking, which may be only partially reversed by the application of $\mathrm{GA}_{4+7}$.

S tayman' apple is a very old cultivar (Beach et al., 1905) prized for its culinary and processing qualities (Dreiling and Williams, 1962). It has been grown in virtually all apple growing regions of the United States from the early 1900 s, but more recently, the bulk of production has been associated with the mid-Atlantic apple growing region. 'Stayman' apples exhibit good fruit size, regular cropping, good storage characteristics, and a finely textured, sprightly flavored flesh. In

U.S. Department of Agriculture, Agricultural Research Service, Appalachian Fruit Research Station, 2217 Wiltshire Road, Kearneysville, WV 25430

Mention of a trademark, proprietary product, or vendor does not constitute a guarantee or warranty of the product by the USDA and does not imply its approval to the exclusion of other products or vendors that also may be suitable.

Appreciation is extended to Milton W. Lover, Statistician, Pennsylvania State University Fruit Research and Extension Center, Biglerville, PA, for his advice and valuable assistance in data analysis and V. Larry Crim, Agricultural Research Technician, for valuable assistance in this study.

${ }^{1}$ Research Horticulturist. E-mail: stephen.miller@ars. usda.gov. the fresh-fruit market, 'Stayman' often receives a premium price $(\mathrm{D}$. Rice, personal communication), making it an attractive cultivar to growers. Despite all its good qualities, 'Stayman' is susceptible to fruit cracking. Characterized by large cracks that develop in the skin and often extend deep into the cortex tissue, cracking can result in preharvest fruit losses of $25 \%$ to $50 \%$ or even more in some years (Byers and Carbaugh, 1995; Gardner and Christ, 1953; Miller, 1990).

Verner (1935) conducted extensive studies on the cracking disorder in 'Stayman' and concluded that a number of factors were associated with cracking, but there was no one single causal factor responsible for the disorder. Various cultural management practices to reduce cracking have been investigated (Opara et al., 1997) and recommendations made (Baugher et al.,1995; Byers et al., 1990; Gardner and Christ, 1953; Opara, 1996; Stiles et al., 1959), but few, if any, of these methods have consistently reduced cracking except the application of plant growth regulators (Byers and Carbaugh, 1995; Byers et al., 1990; Costa et al., 1983; Miller, 1990). Sullivan and Widmoyer (1970) reported that a single spray of daminozide (Alar85; Crompton/Uniroyal Chemical, Middlebury, CT) at 2000 ppm reduced cracking of 'Stayman' apples. Costa et al. (1983) found that four sprays of daminozide at $1000 \mathrm{ppm}$ applied between 42 and 109 d after full bloom significantly reduced cracking in 'Stayman Red' apples. Four sprays at $2000 \mathrm{ppm}$ reduced cracking, but also reduced fruit weight and yield.

A single spray of $1000 \mathrm{ppm}$ daminozide applied on 27 July reduced the percentage of cracked 'Stayman' apples from $58 \%$ to $35 \%$ (Byers et al., 1990). In the same study, four weekly sprays of gibberellins A4 plus A7 $\left(\mathrm{GA}_{4+7}\right)$ at $20 \mathrm{ppm}$ beginning 27 July reduced cracking from $58 \%$ to $21 \%$. In a later study on 'Stayman' showing severe cracking (controls with 95\% cracked fruit), five sprays of $10 \mathrm{ppm}$ $\mathrm{GA}_{4+7}$ alone or combined with one spray of $1000 \mathrm{ppm}$ daminozide reduced cracking by only $\approx 15 \%$. When Byers et al. (1990) added naphthaleneacetic acid (20 ppm) and pinolene (Vapor-Gard; Miller Chemical \& Fertilizer Corp., Hanover, PA) (5 ppm) to the $\mathrm{GA}_{4+7}$ plus daminozide spray solution, cracking was reduced from $95 \%$ to $27 \%$.

Miller (1990) reported that four sprays of $\mathrm{GA}_{4+7}$ applied at either 20 or $50 \mathrm{ppm}$ beginning in early July were

\begin{tabular}{llll}
\hline $\begin{array}{l}\text { Units } \\
\text { To convert U.S. to SI, } \\
\text { multiply by }\end{array}$ & U.S. unit & SI unit & $\begin{array}{l}\text { To convert SI to U.S., } \\
\text { multiply by }\end{array}$ \\
\hline 0.4047 & acre(s) & $\mathrm{ha}$ & 2.4711 \\
3.7854 & gal & $\mathrm{L}$ & 0.2642 \\
9.3540 & gal/acre & $\mathrm{L} \cdot \mathrm{ha}^{-1}$ & 0.1069 \\
2.5400 & inch $(\mathrm{es})$ & $\mathrm{cm}$ & 0.3937 \\
28.3495 & $\mathrm{oz}$ & $\mathrm{g}$ & 0.0353 \\
0.0749 & $\mathrm{oz} / 100 \mathrm{gal}$ & $\mathrm{g} \cdot \mathrm{L}^{-1}$ & 13.3526 \\
1 & $\mathrm{ppm}$ & $\mathrm{mg} \cdot \mathrm{L}^{-1}$ & 1 \\
6.8948 & $\mathrm{psi}$ & $\mathrm{kPa}$ & 0.1450
\end{tabular}


very effective in reducing 'Stayman' cracking even under severe conditions in West Virginia. A study of five concentrations over a range of 0 to $50 \mathrm{ppm} \mathrm{GA}{ }_{4+7}$ produced a curvilinear response; cracking was reduced at 25 and $50 \mathrm{ppm}$ (Miller, 1990). Unrath (1991) in North Carolina reported that five sprays of $\mathrm{GA}_{4+7}$ applied at $50 \mathrm{ppm}$ at 3-week intervals reduced 'Stayman' cracking by $69 \%$ to $82 \%$ compared with controls. The proprietary mixture of $\mathrm{GA}_{4+7}$ (ProVide; Valent BioSciences Corp., Libertyville, IL) received registration from the U.S. Environmental Protection Agency for suppression of 'Stayman' apple cracking in 1990. Current recommendations suggest three to six consecutive sprays of ProVide 10 SG at 100 to $200 \mathrm{~g} / 100$ gal per acre applied at 14- to 21 -d intervals beginning 3 weeks before cracking normally appears (Valent BioSciences Corp., 2005).

The 'Stayman' apple tree is a moderately vigorous to vigorous cultivar. The growth suppressant prohexadione-calcium (PCa) (Apogee; BASF Corp., Agricultural Products Group, Research Triangle Park, NC) has demonstrated excellent shoot growth control in a number of apple cultivars (Greene, 1999; Miller, 2002; Rademacher et al., 2004; Schupp et al., 2001) and would seem a likely candidate to control shoot extension growth in 'Stayman'. PCa inhibits GA metabolism by blocking the conversion of the inactive $\mathrm{GA}_{20}$ to the active $\mathrm{GA}_{1}$, thereby reducing the supply of active GA available for cell elongation (Evans et al., 1999). The question arises, given that PCa is an antigibberellin, will the application of Apogee affect the efficacy of $\mathrm{GA}_{4+7}$ applied to reduce 'Stayman' cracking? The objective of the current study was to examine the efficacy of PCa and $\mathrm{GA}_{4+7}$ on shoot growth and the incidence of fruit cracking in the 'Stayman' apple.

\section{Materials and methods}

To examine the objective, a group of experiments was conducted between 1997 and 2001 in bearing 'Stayman' apple trees growing at the Appalachian Fruit Research Station (AFRS), Kearneysville, WV, or in a commercial orchard near Kearneysville. The strain used in all experiments was 'Stayman 201'. All sprays were applied between 0600 and 0830 HR to facilitate maximum absorption. Sprays were applied at 100 psi with a handgun piston pump sprayer to obtain complete coverage of foliage and fruit to the point of drip. PCa treatments in 1997 and 1998 were applied as a dilute spray at a given concentration. In the 1998 experiment and in all subsequent experiments, ammonium sulfate (AMS) (spray grade) was included as a water conditioner on an equal weight basis with PCa. Beginning in 1999, the final dose for PCa was determined from a specified rate of formulated product in ounces [Apogee 27.5 DF (27.5\% a.i. dry flowable formulation) ] per 100 gal of spray solution adjusted for the calculated tree-row-volume (TRV) (Sutton and Unrath, 1984) in $100 \mathrm{gal} / \mathrm{acre}$. In all experiments, $\mathrm{GA}_{4+7}$ was applied using the proprietary material ProVide (the liquid formulation) supplied by Valent BioSciences Corp. $\mathrm{GA}_{4+7}$ was applied dilute in five sprays at a given concentration at 2-week intervals beginning approximately 1 July. In each case, except for Expt. 1 (described subsequently and in Table 1), the first two $\mathrm{GA}_{4+7}$ sprays were applied at a concentration of $37.5 \mathrm{ppm}$ and the final three sprays were applied at a concentration of $25 \mathrm{ppm}$.

Trees were monitored weekly for signs of fruit cracking from 1 Aug. until harvest (approximately 10 Oct.). Cracked fruit were removed and counted as they appeared. At harvest, all fruit were removed and counted and the total percentage of fruit cracked for the season was calculated. In all but Expt. 2, the length of the current season's shoot growth was measured in November on 10 to 20 terminals selected at random on the periphery of the canopy and used to calculate mean terminal shoot growth. Total yield was determined by harvesting all fruit from individual trees and mean fruit weight determined by measuring a minimum of 50 fruit per tree (except for Expt. 2). Data from each experiment were analyzed using a one- or two-way analysis of variance (ANOVA), as appropriate, and treatment means separated by Fisher's protected least significant difference at $P \leq 0.10$. A check of residuals indicated that a transformation of the percentage data was not appropriate or necessary for any of the variables in any of the experiments. In Expt. 2, data were subjected to a twoway ANOVA and main treatment effects separated using contrast statements.

EXPT. 1. The trees selected were on 'Malling Merton.111' (MM.111) rootstock and beginning their seventh leaf in the orchard. All trees were dormant pruned before the application of treatments in May 1997 and were characterized as highly vigorous. PCa was applied as BAS $12510 \mathrm{~W}$ ( $10 \%$ a.i. dry flowable formulation) with the nonionic adjuvant Regulaid (2-butoxyethanol, poloxalene, monopropylene glycol; Kalo, Overland Park, KS) included at $0.03 \%(\mathrm{v} / \mathrm{v})$. Sprays were designated as either a postbloom (applied in May or June) or a preharvest (applied in July and Aug.) spray, depending on the period in which it was applied. The concentration for individual spray applications and the dates of application for individual treatments are given in Table 1. The initial postbloom PCa spray was applied on 2 May when shoot growth averaged $\approx 2.75$ inches. Subsequent postbloom PCa sprays were applied at 4 weeks or 6 weeks after the initial spray. In three of the treatments, a postbloom PCa spray schedule was combined with three or four low-dose $(75 \mathrm{ppm})$ preharvest PCa sprays. Preharvest PCa sprays were initiated on 3 July or 18 July and $\mathrm{GA}_{4+7}$ sprays were begun on 3 July (Table 1). Treatments were applied to whole trees in five randomized complete blocks. The number and length of water sprouts produced at the large pruning cuts on the central leader were recorded.

EXPT. 2. In 1998, sprays of PCa (BAS 125W 27.5DF) (27.5\% a.i. dry flowable formulation) or $\mathrm{GA}_{4+7}$ were applied to 7 -year-old trees growing on several semidwarf rootstocks ['Malling.7' (M.7), M.9/MM.111, and MM.111]. All treatments were assigned equally across the rootstocks with single tree replicates in five randomized complete blocks. Regulaid was included in all sprays at $0.03 \%$ $(\mathrm{v} / \mathrm{v})$. The initial PCa spray was applied on 6 May when new shoot growth averaged 4 to 6 inches in length. The second PCa spray was applied 4 weeks later on 3 June. The rate of $\mathrm{PCa}$ for individual treatments is given in Table 2. $\mathrm{GA}_{4+7}$ was applied beginning on 14 July. 
Table 1. Effect of prohexadione-calcium (PCa) and gibberellin A4 plus A7 $\left(\mathrm{GA}_{4+7}\right)$ on shoot growth and fruit cracking in Stayman 201 apple (Expt. 1-1997). ${ }^{\mathrm{z}}$

\begin{tabular}{|c|c|c|c|c|c|c|}
\hline \multicolumn{4}{|c|}{ Treatment } & \multirow{2}{*}{$\begin{array}{c}\text { Terminal } \\
\text { shoot length } \\
(\mathrm{cm})^{\mathrm{x}}\end{array}$} & \multirow{2}{*}{$\begin{array}{c}\begin{array}{c}\text { Length of } \\
\text { water sprouts } \\
(\mathrm{cm})\end{array} \\
\end{array}$} & \multirow[b]{2}{*}{$\begin{array}{l}\text { Cracked } \\
\text { fruit (\%) }\end{array}$} \\
\hline $\begin{array}{l}\mathrm{PCa} \\
(\mathrm{ppm})^{\mathrm{y}}\end{array}$ & $\begin{array}{c}\text { Application } \\
\text { date }\end{array}$ & $\begin{array}{l}\mathrm{GA}_{4+7} \\
(\mathrm{ppm})\end{array}$ & $\begin{array}{c}\text { Application } \\
\text { date }\end{array}$ & & & \\
\hline $125,125,75$ & 2 May, 30 May, 18 July & 0 & - & & & \\
\hline $75,75,75$ & 1 Aug., 15 Aug., 29 Aug. & & & $29.6 b^{v}$ & $40.4 \mathrm{bc}$ & $74.6 \mathrm{ab}$ \\
\hline $250,75,75$ & 2 May, 18 July, 1 Aug. & 0 & - & & & \\
\hline 75,75 & 15 Aug., 29 Aug. & & & $30.4 \mathrm{~b}$ & $26.4 \mathrm{c}$ & $80.2 \mathrm{a}$ \\
\hline $125,250,50$ & 2 May, 11 June, 3 July & 0 & - & & & \\
\hline 50,50 & 1 Aug., 29 Aug. & & & $27.6 \mathrm{~b}$ & $36.6 \mathrm{c}$ & $77.7 \mathrm{ab}$ \\
\hline $125,125,125$ & 2 May, 30 May, 11 June & $\begin{array}{l}37.5,37.5,25 \\
25,25\end{array}$ & $\begin{array}{l}3 \text { July, } 18 \text { July, } 1 \text { Aug. } \\
15 \text { Aug., } 29 \text { Aug. }\end{array}$ & $32.6 \mathrm{~b}$ & $61.8 \mathrm{ab}$ & $48.6 \mathrm{c}$ \\
\hline 250,125 & 2 May, 30 May & $\begin{array}{l}37.5,25,25 \\
25,25\end{array}$ & $\begin{array}{l}3 \text { July, } 18 \text { July, } 1 \text { Aug. } \\
15 \text { Aug., } 29 \text { Aug. }\end{array}$ & $30.6 \mathrm{~b}$ & $71.4 \mathrm{a}$ & $71.0 \mathrm{ab}$ \\
\hline 0 & - & $37.5,37.5,25$ & 3 July, 18 July, 1 Aug. & & & \\
\hline 0 & - & $\begin{array}{r}25,25 \\
0\end{array}$ & $\begin{array}{c}15 \text { Aug., } 29 \text { Aug. } \\
\frac{-}{P}\end{array}$ & $\begin{array}{c}49.2 \mathrm{a} \\
46.6 \mathrm{a} \\
0.0007\end{array}$ & $\begin{array}{c}72.0 \mathrm{a} \\
76.6 \mathrm{a} \\
0.0084\end{array}$ & $\begin{array}{l}21.6 \mathrm{~d} \\
63.8 \mathrm{~b} \\
0.0001\end{array}$ \\
\hline
\end{tabular}

${ }^{2}$ Sprays applied dilute with handgun sprayer to drip. PCa applied as BAS 125 10W (BASF Corp., Agricultural Products Group, Research Triangle Park, NC) and GA ${ }_{4+7}$ applied as ProVide (Valent BioSciences Corp., Libertyville, IL). Regulaid (Kalo, Overland Park, KS) included at $0.03 \%$ (v/v).

${ }^{\mathrm{y}} \mathrm{l} \mathrm{ppm}=\mathrm{l} \mathrm{mg} \cdot \mathrm{L}^{-1}$.

${ }^{\mathrm{x}} 1 \mathrm{~cm}=0.3937$ inch.

"Shoots produced on central leader at sites of large pruning cuts.

"Data analyzed using one-way analysis of variance. Mean separation within columns by Fisher's protected least significant difference at $P \leq 0.10$.

Table 2. Effect of prohexadione-calcium (PCa) and gibberellin A4 plus A7 $\left(\mathrm{GA}_{4+7}\right)$ on fruit cracking in Stayman 201 apple trees on several rootstocks (Expt. 2-1998). ${ }^{\mathrm{z}}$

\begin{tabular}{ccc}
\hline \multicolumn{2}{c}{ Treatment } & \\
\cline { 1 - 2 } $\mathbf{P C a}^{\mathbf{y}}$ & Gacked fruit (\%) \\
\cline { 1 - 2 } & $(\mathbf{p p m})^{\mathbf{w}}$ & $18.5 \mathrm{ab}^{\mathrm{v}}$ \\
0 & 0 & $7.4 \mathrm{~b}$ \\
0 & $37.5,37.5,25,25,25$ & $30.0 \mathrm{a}$ \\
125,250 & 0 & $16.5 \mathrm{ab}$ \\
125,250 & $37.5,37.5,25,25,25$ & $12.0 \mathrm{~b}$ \\
250,125 & $37.5,37.5,25,25,25$ & $16.1 \mathrm{ab}$
\end{tabular}

Subset analysis for fruit cracking $(\%)$ with $\mathrm{PCa}(-\mathrm{or}+)$ or $\mathrm{GA}_{4+7}(-\mathrm{or}+)$ as a contrast using all treatments above $\mathrm{e}^{\mathrm{u}}$ :

\begin{tabular}{lcccc}
\hline & \multicolumn{5}{c}{ PCa } & \\
\cline { 2 - 4 } $\mathbf{G A}_{4+7}$ & - & + & Mean & \multicolumn{1}{c}{$\boldsymbol{P}$} \\
\hline- & 18.5 & 30.0 & $24.2 \mathrm{a}$ & \\
& & & & 0.0502 \\
+ & 7.4 & 16.5 & $12.0 \mathrm{~b}$ & \\
Mean & $13.0 \mathrm{~b}$ & $23.3 \mathrm{a}$ & & \\
$P$ & 0.0962 & & & \\
\hline
\end{tabular}

${ }^{2}$ Sprays applied dilute with handgun sprayer to drip. PCa applied as BAS 125 27.5DF (BASF Corp., Agricultural Products Group, Research Triangle Park, NC) and $\mathrm{GA}_{4+7}$ applied as ProVide (Valent BioSciences Corp., Libertyville, IL). Regulaid (Kalo, Overland Park, KS) included at $0.03 \%(\mathrm{v} / \mathrm{v})$. PCa sprays included ammonium sulfate as a water conditioner on an equal weight basis with PCa.

'Initial spray applied 6 May at 4 to 6 inches growth stage $(1$ inch $=2.54 \mathrm{~cm})$; second spray applied 3 June.

"Five sprays applied, one each on 14 July, 28 July, 16 Aug., 25 Aug., and 8 Sept. at concentration indicated.

" $1 \mathrm{ppm}=1 \mathrm{mg} \cdot \mathrm{L}^{-1}$.

'One-way analysis of variance; mean separation by Fisher's protected least significant difference at $P \leq 0.10$.

uTwo-way analysis of variance; interaction $P=0.8430$.

ExpT. 3. A group of 8-year-old trees on MM.11l was selected for treatment in 1999. Treatments were arranged in a $2 \times 4$ factorial with PCa and $\mathrm{GA}_{4+7}$ (Table 3 ). Four rates of
PCa $[0,3,6$, and $12 \mathrm{oz} / 100 \mathrm{gal}$ TRV formulated product (Apogee 27.5DF)] were selected for application at three postbloom timings [petal fall $(\mathrm{PF})+$ $7 \mathrm{~d}, \mathrm{PF}+28 \mathrm{~d}$, and $\mathrm{PF}+42 \mathrm{~d}]$ with or without preharvest $\mathrm{GA}_{4+7}$ sprays (Table 3). The calculated TRV for the test plot was $330 \mathrm{gal} /$ acre and the calculated PCa dose was applied in a carrier volume of $164 \mathrm{gal} / \mathrm{acre}$. Regulaid was included at $0.03 \%(\mathrm{v} / \mathrm{v})$ in all $\mathrm{PCa}$ sprays. Bio-88, a nonionic spreader-activator (blend of alkylarylpolyethoxyethanol, free fatty acids, 2butylether, and dimethylpolysiloxane; Kalo) was included in all $\mathrm{GA}_{4+7}$ sprays at $0.03 \%(\mathrm{v} / \mathrm{v})$.

ExPT. 4. Treatments of PCa and $\mathrm{GA}_{4+7}$ were arranged as a $2 \times 2$ factorial (Table 4) and applied to mature bearing trees on M.7 rootstock in a commercial orchard near Kearneysville, WV, in 2000. Forty uniform trees with moderate to heavy cropping potential, based on bloom density, were selected and assigned to four treatments with 10 single-tree replications in a randomized complete block design. PCa was applied in two sprays, the first on 3 May when shoot growth averaged 3 inches and the second spray 3 weeks later on 24 May. The initial PCa spray was applied at a rate based on $12 \mathrm{oz} /$ 100 gal TRV formulated product (Apogee 27.5DF) and the second spray was applied at a rate based on $6 \mathrm{oz} / 100 \mathrm{gal}$ TRV. The calculated TRV for the test orchard was 290 gal/acre. Spray treatments were applied in a carrier volume of 100 gal/acre. Regulaid was included in all 
Table 3. Effect of prohexadione-calcium (PCa) and gibberellin A4 plus A7 (GA $4+7)$ on shoot growth and fruit cracking in Stayman 201 apple trees (Expt. 3-1999). ${ }^{\mathrm{z}}$

\begin{tabular}{|c|c|c|c|c|c|c|c|c|c|}
\hline \multicolumn{8}{|c|}{ Treatment } & \multirow{3}{*}{$\begin{array}{l}\text { Terminal shoot } \\
\text { length }(\mathrm{cm})^{v}\end{array}$} & \multirow{3}{*}{$\begin{array}{l}\text { Cracked } \\
\text { fruit (\%) }\end{array}$} \\
\hline \multicolumn{3}{|c|}{$\overline{\mathrm{PCa}\left(\mathrm{oz} / 100 \text { gal TRV) applied }^{\mathrm{y}}\right.}$} & \multicolumn{5}{|c|}{$\mathrm{GA}_{4+7}(\mathrm{ppm})^{\mathrm{x}}$ applied } & & \\
\hline$\underline{\mathrm{PF}+7^{\mathrm{w}}}$ & $\mathrm{PF}+28$ & $\mathrm{PF}+42$ & I July & 15 July & 29 July & 12 Aug. & 26 Aug. & & \\
\hline 0 & 0 & 0 & 37.5 & 37.5 & 25 & 25 & 25 & 33.6 & 19.4 \\
\hline 6 & 3 & 0 & 0 & 0 & 0 & 0 & 0 & 23.8 & 58.2 \\
\hline 6 & 3 & 0 & 37.5 & 37.5 & 25 & 25 & 25 & 24.7 & 29.5 \\
\hline 12 & 6 & 0 & 0 & 0 & 0 & 0 & 0 & 22.4 & 69.2 \\
\hline 12 & 6 & 0 & 37.5 & 37.5 & 25 & 25 & 25 & 31.4 & 44.6 \\
\hline
\end{tabular}

Two-way analysis of variance for terminal shoot length $(\mathrm{cm})$ with PCa (four treatment levels) and $\mathrm{GA}_{4+7}(- \text { or }+)^{\mathrm{u}}$ :

\begin{tabular}{|c|c|c|c|c|c|c|}
\hline \multirow[b]{2}{*}{$\underline{\mathbf{G A}_{4+7}}$} & \multicolumn{6}{|c|}{$\mathrm{PCa}$} \\
\hline & 0-0-0 & 6-3-0 & $6-6-6$ & $12-6-0$ & Mean & $P$ \\
\hline- & 39.6 & 23.8 & 18.5 & 22.4 & $26.6 \mathrm{a}$ & \\
\hline+ & 33.6 & 24.7 & 27.7 & 31.4 & $29.5 \mathrm{a}$ & \\
\hline $\begin{array}{l}\text { Mean } \\
P\end{array}$ & $36.6 \mathrm{a}$ & $\begin{array}{r}24.3 \mathrm{~b} \\
0\end{array}$ & $23.1 \mathrm{~b}$ & $26.0 \mathrm{~b}$ & & \\
\hline
\end{tabular}

\begin{tabular}{|c|c|c|c|c|c|c|}
\hline \multirow[b]{2}{*}{$\underline{\mathbf{G A}_{4+7}}$} & \multicolumn{5}{|c|}{ PCa } & \\
\hline & $0-0-0$ & 6-3-0 & $6-6-6$ & 12-6-0 & Mean & \\
\hline- & 48.0 & 58.2 & 53.5 & 69.2 & $57.3 \mathrm{a}$ & \multirow[t]{3}{*}{0.0001} \\
\hline+ & 19.4 & 29.5 & 27.6 & 44.6 & $29.0 \mathrm{~b}$ & \\
\hline $\begin{array}{l}\text { Mean } \\
P \\
\end{array}$ & \multicolumn{5}{|c|}{0.0017} & \\
\hline
\end{tabular}

sprays at $0.125 \%(\mathrm{v} / \mathrm{v})$ and the final spray solution was adjusted to $\mathrm{pH} 6.0$ with distilled white vinegar.

ExpT. 5. In 2000, a study was conducted to examine the effect of several spray adjuvants in combination with $\mathrm{PCa}$ on the incidence of 'Stayman' cracking. Seven treatments were assigned at random to single 9year-old trees on MM.111 rootstock in seven replicated plots. Five adjuvants were evaluated in combination with PCa: Regulaid, Bio-88, Silwet L77 (polyalkyleneoxide-modified heptamethyltrisiloxane; Helena Chemical Co., Collierville, TN), DyneAmic (a proprietary blend of polyalkyleneoxide modified polydimethyltrisiloxane, nonionic emulsifiers, and methylated vegetable oils; Helena Chemical Co.), and Damoil (70-s delayed dormant spray oil; Drexel Chemical Co., Memphis, TN). Adjuvants were used at the manufacturer's suggested concentration (Table 5). PCa was applied in two sprays at $6 \mathrm{oz} / 100 \mathrm{gal} \mathrm{TRV}$ (as Apogee $27.5 \mathrm{DF}$ ) per spray. The initial spray was applied on 27 Apr. when terminal shoot growth averaged 6.6 $\mathrm{cm}$ in length. The second spray was applied on 12 May. The calculated TRV for test plot trees was $400 \mathrm{gal} /$ acre and sprays were applied in a carrier volume of $100 \mathrm{gal} / \mathrm{acre}$. The final spray solution was adjusted to pH 6.5 with distilled white vinegar.

ExpT. 6. Spray treatments applied in Expt. 4 were repeated in 2001 on a group of 10-year-old trees on MM.111 rootstock growing at the AFRS location (Table 6). Four treatments were assigned to 11 single-tree replications in a randomized complete-block design. The initial PCa spray was applied on 8 May when terminal growth averaged $7.3 \mathrm{~cm}$ in length. The second PCa spray was applied on 24 May. The calculated TRV for the test trees was $390 \mathrm{gal} /$ acre and all sprays were applied in a carrier volume of $270 \mathrm{gal} /$ acre.

\section{Results}

Expт. 1. Mean yield per tree and fruit weight did not differ among treatments (data not shown). All treatments that included PCa reduced the length of terminal shoots (Table 1). Five preharvest $\mathrm{GA}_{4+7}$ sprays alone had no effect on terminal shoot length or the length of water sprouts. When PCa was applied in 
Table 4. Shoot growth and fruit cracking in Stayman 201 apple trees treated with prohexadione-calcium (PCa) or gibberellin A4 plus A7 $\left(\mathrm{GA}_{4+7}\right)$ (Expt. 4-2000). ${ }^{\mathrm{z}}$

Two-way analysis of variance for terminal shoot length $(\mathrm{cm})$ with $\mathrm{PCa}(-$ or +$)$ and $\mathrm{GA}_{4+7}$ $(- \text { or }+)^{\mathrm{y}}$ :

\begin{tabular}{lcccc}
\hline & \multicolumn{3}{c}{ PCa } & Mean \\
\cline { 2 - 4 } $\mathbf{G A}_{\mathbf{4}+7}$ & - & + & $17.5 \mathrm{a}$ & $\boldsymbol{P}$ \\
\hline- & 24.2 & 10.7 & & 0.9913 \\
+ & 24.2 & 10.8 & $17.5 \mathrm{a}$ & \\
Mean & $24.2 \mathrm{~b}$ & $10.8 \mathrm{a}$ & & \\
$P$ & 0.0028 & & &
\end{tabular}

$\underline{\text { Two-way analysis of variance for fruit cracking }(\%) \text { with PCa }(- \text { or }+) \text { and } \mathrm{GA}_{4+7}(-\mathrm{or}+)^{\mathrm{x}} \text { : }}$

\begin{tabular}{|c|c|c|c|c|}
\hline \multirow[b]{2}{*}{$\mathbf{G A}_{4+7}$} & \multicolumn{3}{|c|}{ PCa } & \multirow[b]{2}{*}{$P$} \\
\hline & - & + & Mean & \\
\hline- & 34.1 & 54.4 & $44.2 \mathrm{a}$ & \\
\hline & & & & 0.1650 \\
\hline+ & 25.5 & 40.4 & $32.9 \mathrm{a}$ & \\
\hline Mean & $29.8 \mathrm{~b}$ & $47.4 \mathrm{a}$ & & \\
\hline$P$ & 0.0346 & & & \\
\hline
\end{tabular}

${ }^{\mathrm{z}}$ Sprays applied dilute with handgun sprayer to drip. PCa applied as Apogee 27.5DF (BASF Corp., Agricultural Products Group, Research Triangle Park, NC) in two sprays at $100 \mathrm{gal} /$ acre based on a tree-row-volume (TRV) of $290 \mathrm{gal} / \mathrm{acre}$; initial spray applied on $3 \mathrm{May}$ at $12 \mathrm{oz} / 100 \mathrm{gal}\left(0.90 \mathrm{~g} \cdot \mathrm{L}^{-1}\right) \mathrm{TRV}$ and second spray applied $24 \mathrm{May}$ at $6 \mathrm{oz} / 100 \mathrm{gal}$ TRV. PCa sprays included ammonium sulfate as a water conditioner on an equal weight basis with PCa and Regulaid (Kalo, Overland Park, KS) at $0.125 \%(\mathrm{v} / \mathrm{v})$. Final spray solution adjusted to $\mathrm{pH} 6.0$ with distilled white vinegar. $\mathrm{GA}_{4+7}$ applied as ProVide (Valent BioSciences Corp., Libertyville, IL) in five sprays at 2 -week intervals with initial spray applied on 30 June. First two sprays applied at concentration of $37.5 \mathrm{ppm}$ and last three sprays applied at $25 \mathrm{ppm}$. Regulaid included in all sprays at $0.125 \%(\mathrm{v} / \mathrm{v})\left(1 \mathrm{gal} / \mathrm{acre}=9.3540 \mathrm{~L} \cdot \mathrm{ha}^{-1}\right.$, $\left.1 \mathrm{oz} / 100 \mathrm{gal}=0.0749 \mathrm{~g} \cdot \mathrm{L}^{-1}, 1 \mathrm{ppm}=1 \mathrm{mg} \cdot \mathrm{L}^{-1}\right)$.

'Mean separation by Fisher's protected least significant difference (LSD) at $P \leq 0.10$. Interaction $P=0.9913$.

${ }^{x}$ Mean separation by Fishers protected LSD at $P \leq 0.10$. Interaction $P=0.7417$.

Table 5. Effect of prohexadione-calcium (PCa) alone or combined with several spray adjuvants on terminal shoot length and fruit cracking in Stayman 201 apple trees (Expt. 5-2000).

\begin{tabular}{|c|c|c|c|c|}
\hline \multicolumn{3}{|c|}{ Treatment $^{\mathrm{z}}$} & \multirow{2}{*}{$\begin{array}{c}\text { Terminal shoot } \\
\text { length }(\mathrm{cm})\end{array}$} & \multirow{2}{*}{$\begin{array}{l}\text { Cracked } \\
\text { fruit (\%) }\end{array}$} \\
\hline$\overline{\text { Adjuvant }^{\mathrm{y}}}$ & Concn $(\% \mathrm{v} / \mathrm{v})$ & PCa $(-$ or +$)$ & & \\
\hline None & 0 & - & $26.4 \mathrm{a}^{\mathrm{x}}$ & $25.7 \mathrm{c}$ \\
\hline None & 0 & + & $17.5 \mathrm{~b}$ & $36.9 \mathrm{bc}$ \\
\hline Silwet L77 & 0.062 & + & $17.5 \mathrm{~b}$ & $52.6 \mathrm{ab}$ \\
\hline Regulaid & 0.125 & + & $19.0 \mathrm{~b}$ & $49.3 \mathrm{~b}$ \\
\hline Bio-88 & 0.125 & + & $18.3 \mathrm{~b}$ & $49.5 \mathrm{~b}$ \\
\hline Damoil & 0.250 & + & $18.7 \mathrm{~b}$ & $45.4 \mathrm{~b}$ \\
\hline \multirow[t]{2}{*}{ DyneAmic } & 0.380 & + & $18.9 \mathrm{~b}$ & $71.6 \mathrm{a}$ \\
\hline & & $P$ & 0.0001 & 0.0124 \\
\hline
\end{tabular}

${ }^{\mathrm{z}}$ Sprays applied with handgun sprayer to wet fruit and foliage (drip). PCa applied as Apogee 27.5DF (BASF Corp., Agricultural Products Group, Research Triangle Park, NC) in two sprays at $6 \mathrm{oz} / 100$ gal tree-row-volume (TRV) each based on a calculated TRV of $400 \mathrm{gal} /$ acre in a carrier spray volume of $100 \mathrm{gal} / \mathrm{acre}$; initial spray applied on 27 Apr. and second spray applied 12 May. PCa sprays included ammonium sulfate as a water conditioner on an equal weight basis with PCa. Spray solution adjusted to $\mathrm{pH} 6.5$ with distilled white vinegar $\left(\mathrm{loz} / 100 \mathrm{gal}=0.0749 \mathrm{~g} \cdot \mathrm{L}^{-1}\right.$, $1 \mathrm{gal} /$ acre $=9.3540 \mathrm{~L} \cdot \mathrm{ha}^{-1}$ ).

ySilwet L77 and DyneAmic, Helena Chemical Co., Collierville, TN; Regulaid and Bio-88, Kalo, Overland Park, KS; and Damoil (70-s delayed dormant spray oil), Drexel Chemical Co., Memphis, TN.

${ }^{x}$ Mean separation within columns by Fisher's protected least significant difference at $P \leq 0.10$.

two or three postbloom sprays followed by preharvest $\mathrm{GA}_{4+7}$ sprays, terminal growth was reduced similar to that on trees treated with postbloom plus preharvest PCa alone. Water sprout growth was reduced on trees treated with postbloom plus preharvest PCa. The length of water sprouts was unaffected when PCa was applied postbloom only followed by $\mathrm{GA}_{4+7}$ preharvest sprays. Five preharvest sprays of $\mathrm{GA}_{4+7}$ alone reduced fruit cracking from $64 \%$ (considered severe) to $22 \%$ (moderately low). A single postbloom PCa spray at 250 ppm followed by four preharvest PCa sprays at $75 \mathrm{ppm}$ each increased the level of fruit cracking. The level of fruit cracking was unaffected when two postbloom PCa sprays were applied, the initial spray at $125 \mathrm{ppm}$, followed by three or four preharvest PCa sprays (Table 1). Three postbloom PCa sprays at 125 ppm each followed by the preharvest $\mathrm{GA}_{4+7}$ treatment reduced fruit cracking compared with controls, but the level of cracking was still greater than that obtained with the $\mathrm{GA}_{4+7}$ treatment alone. When two postbloom PCa sprays were applied, the initial spray at $250 \mathrm{ppm}$, followed by preharvest $\mathrm{GA}_{4+7}$, the percentage of fruit cracking did not differ from the controls.

ExpT. 2. Preharvest $\mathrm{GA}_{4+7}$ sprays reduced the percent of cracked fruit by $60 \%$ compared with the control (Table 2). Trees treated with PCa alone had significantly more cracked fruit than trees treated with $\mathrm{GA}_{4+7}$ alone. Applying $\mathrm{GA}_{4+7}$ as a preharvest treatment to trees that received postbloom PCa sprays reduced cracking by $45 \%$ to $60 \%$ compared with trees treated with PCa alone. A two-way ANOVA of the data set with contrast statements showed that $\mathrm{PCa}$ increased cracking, whereas $\mathrm{GA}_{4+7}$ treatment reduced fruit cracking. The two-way interaction of PCa $\times$ $\mathrm{GA}_{4+7}$ was nonsignificant $(P=$ $0.8430)$.

ExpT. 3. A two-way analysis of the main treatment effects showed no significant effect of $\mathrm{GA}_{4+7}$ on terminal shoot length, but a significant reduction in terminal length with PCa at all treatment levels (Table 3 ). The interaction between PCa and $\mathrm{GA}_{4+7}$ for terminal shoot length was significant $(P=0.0741)$.

Across all treatments, spraying 'Stayman 201' apple trees with $\mathrm{GA}_{4+7}$ reduced fruit cracking in 1999 (Table 3). $\mathrm{GA}_{4+7}$ alone reduced the percentage of cracked fruit from $48 \%$ to $19 \%$, a $60 \%$ reduction in fruit cracking. PCa generally increased fruit cracking. Trees treated with $\mathrm{PCa}$ at $12 \mathrm{oz} / 100 \mathrm{gal} \mathrm{TRV}$ at the $\mathrm{PF}+7 \mathrm{~d}$ timing followed by a second spray at $\mathrm{PF}+28 \mathrm{~d}$ at $6 \mathrm{oz} / 100 \mathrm{gal}$ TRV exhibited the highest percentage of cracked fruit. Trees treated at the lowest total PCa dose rate $(6 \mathrm{oz} /$ $100 \mathrm{gal}$ at $\mathrm{PF}+7 \mathrm{~d}$ followed by $3 \mathrm{oz} /$ 100 gal at $P F+28 d$ ) also showed an increase in the percentage of cracked fruit compared with the non-PCatreated control trees. When PCa was applied in three equal rate sprays (6 
Table 6. Shoot growth and fruit cracking in Stayman 201 apple trees treated with prohexadione-calcium (PCa) or gibberellin A4 plus A7 $\left(\mathrm{GA}_{4+7}\right)$ (Expt. 6-2001).

Two-way analysis of variance for terminal shoot length $(\mathrm{cm})$ with PCa $(-$ or +$)$ and $\mathrm{GA}_{4+7}$ $(- \text { or }+)^{\mathrm{y}}$ :

\begin{tabular}{lcccc}
\hline & \multicolumn{3}{c}{ PCa } & \\
\cline { 2 - 4 } $\mathbf{G A}_{\mathbf{4}+\mathbf{7}}$ & - & + & Mean & $\boldsymbol{P}$ \\
\hline- & 46.2 & 20.5 & $33.3 \mathrm{~b}$ & \\
& & & & 0.0531 \\
+ & 49.8 & 26.8 & $38.3 \mathrm{a}$ & \\
Mean & $48.0 \mathrm{~b}$ & $23.6 \mathrm{a}$ & & \\
$P$ & 0.0001 & & &
\end{tabular}

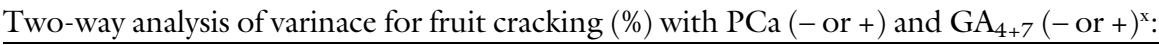

\begin{tabular}{|c|c|c|c|c|}
\hline \multirow[b]{2}{*}{$\underline{\mathbf{G A}_{4+7}}$} & \multicolumn{3}{|c|}{$\mathrm{PCa}$} & \multirow[b]{2}{*}{$P$} \\
\hline & - & + & Mean & \\
\hline - & 11.7 & 24.9 & $18.3 \mathrm{a}$ & \\
\hline+ & 6.1 & 9.4 & $7.7 \mathrm{~b}$ & 0.0001 \\
\hline $\begin{array}{l}\text { Mean } \\
P\end{array}$ & $\begin{array}{l}8.9 \mathrm{~b} \\
0.0001\end{array}$ & $17.2 \mathrm{a}$ & & \\
\hline
\end{tabular}

${ }^{\mathrm{z}}$ Sprays applied dilute with handgun sprayer to drip. PCa applied as Apogee 27.5DF (BASF Corp., Agricultural Products Group, Research Triangle Park, NC) in two sprays at 270 gal/acre based on a tree-row-volume (TRV) of $390 \mathrm{gal} / \mathrm{acre}$; initial spray applied on 8 May at $12 \mathrm{oz} / 100 \mathrm{gal}$ TRV and second spray applied 24 May at $6 \mathrm{oz} / 100$ gal TRV. PCa sprays included ammonium sulfate as a water conditioner on an equal weight basis with PCa and Regulaid (Kalo, Overland Park, KS) at $0.125 \%(\mathrm{v} / \mathrm{v})$. Final spray solution adjusted to $\mathrm{pH} 6.0$ with distilled white vinegar. $\mathrm{GA}_{4+7}$ applied as ProVide (Valent BioSciences Corp., Libertyville, IL) in five sprays at 2-week intervals with initial spray applied on 1 July. First two sprays applied at concentration of $37.5 \mathrm{ppm}$ and last three sprays applied at $25 \mathrm{ppm}$. Regulaid included in all sprays at $0.125 \%(\mathrm{v} / \mathrm{v})\left(1 \mathrm{gal} / \mathrm{acre}=9.3540 \mathrm{~L} \cdot \mathrm{ha}^{-1}, \mathrm{l} \mathrm{oz} / 100 \mathrm{gal}=\right.$ $\left.0.0749 \mathrm{~g} \cdot \mathrm{L}^{-1}, \mathrm{l} \mathrm{ppm}=1 \mathrm{mg} \cdot \mathrm{L}^{-1}\right)$.

'Mean separation by Fisher's protected least significant difference (LSD) at $P \leq 0.10$. Interaction $P=0.5961$

${ }^{x}$ Mean separation by Fisher's protected LSD at $P \leq 0.10$. Interaction $P=0.0139$.

$\mathrm{oz} / 100 \mathrm{gal})$, the percentage of cracked fruit did not differ from control trees. At each PCa treatment level, the percentage of cracked fruit at harvest was reduced when $\mathrm{GA}_{4+7}$ was applied, but the percent reduction was less than that obtained in the non-PCa-treated trees. The PCa and $\mathrm{GA}_{4+7}$ interaction was not significant $(P=0.9617)$

ExpT. 4. Mean yield per tree and fruit weight did not differ among treatments (data not shown). Two sprays of PCa reduced terminal shoot length an average of $56 \%$ (Table 4). $\mathrm{GA}_{4+7}$ sprays applied preharvest alone or to trees previously treated with PCa had no effect on terminal shoot length. The interaction of $\mathrm{PCa}$ and $\mathrm{GA}_{4+7}$ for terminal shoot length was not significant $(P=0.9913)$. Based on the twoway analysis of fruit cracking data, PCa treatment increased fruit cracking, but $\mathrm{GA}_{4+7}$ treatment failed to reduce cracking, although the percentage of cracked fruit declined slightly from $\approx 44 \%$ to $\approx 33 \%$ (Table 4 ).

EXPт. 5. Two postbloom sprays of PCa alone or combined with one of five different spray adjuvants reduced terminal shoot length of 'Stayman 201 ' trees (Table 5). There were no differences in terminal shoot length among the five adjuvants tested. The percentage of cracked fruit was increased on all trees sprayed with PCa plus an adjuvant, but not on the trees treated with PCa minus an adjuvant. The highest percentage of cracked fruit occurred with PCa plus Silwet L77 or DyneAmic, both organosilicone adjuvants (Table 5). In general, the addition of a spray adjuvant to the $\mathrm{PCa}$ spray treatment increased the percentage of cracked fruit by $45 \%$ on the 'Stayman' apples in the test plot. Spraying with PCa alone increased the percentage of cracked fruit by $44 \%$.

Expт. 6. Mean yield per tree and fruit weight did not differ among treatments (data not shown). Two sprays of PCa applied in May reduced terminal shoot length (Table 6). Five $\mathrm{GA}_{4+7}$ sprays at 2 -week intervals beginning I July increased terminal shoot length, but only an average of $5 \mathrm{~cm}$. The interaction of $\mathrm{PCa}$ and $\mathrm{GA}_{4+7}$ for terminal shoot length was not significant $(P=0.5961)$. $\mathrm{GA}_{4+7}$ treatment significantly reduced the percentage of cracked fruit, whereas PCa treatment increased the percentage of cracked fruit, an increase of $\approx 93 \%$ (Table 6). A significant interaction $(P=0.0139)$ existed between $\mathrm{PCa}$ and $\mathrm{GA}_{4+7}$ treatment for fruit cracking. $\mathrm{GA}_{4}+7$ was more efficient in reducing the percentage of cracked fruit in PCa-treated trees than in trees that had not been treated with PCa.

\section{Discussion}

In the present study, PCa was generally applied in multiple sprays at rates of $125 \mathrm{ppm}(6 \mathrm{oz} / 100 \mathrm{gal})$ or $250 \mathrm{ppm}(12 \mathrm{oz} / 100 \mathrm{gal})$ or combinations of these rates. In several experiments (Expt. 1, 2, and 3), lower dose $[50 \mathrm{ppm}, 63 \mathrm{ppm}(3 \mathrm{oz} / 100$ gal), or $75 \mathrm{ppm}$ ] treatments were applied, but these were the exception. The higher rates and multiple spray applications used in these experiments conform to label recommendations for growth control in moderate to vigorous trees (BASF Corp., 2001) and published reports on the use of PCa in the mid-Atlantic region (Byers and Yoder, 1999; Byers et al., 2004a; Miller, 2002).

Yield and fruit weight were unaffected by the application of PCa in this study. Some previous studies have reported increases in fruit set and yield after PCa sprays (Byers et al., 2004a; Glenn and Miller, 2005; Greene, 1999; Medjdoub et al., 2005; Schupp et al., 2003), whereas other studies found no effect on fruit set and yield (Byers and Yoder, 1999; Miller, 2002; Medjdoub et al., 2005; Schupp et al., 2003). Reports on the effect of PCa on fruit size have also varied with some showing reduced fruit size after PCa treatment (Glenn and Miller, 2005; Greene, 1999; Medjdoub et al., 2005; Schupp et al., 2003), but other studies have found no effect (Byers and Yoder, 1999; Miller, 2002; Schupp et al., 2003). It is unclear how PCa may lead to increased fruit set, but Rademacher et al. (1998) suggest it may be related to the ability of PCa to block the conversion of 1-amino-cyclopropane-1-carboxylic acid to ethylene, the abscission hormone. Greene (1999) attributed reduced fruit size after PCa to an increase in fruit set. Studies by Glenn and Miller (2005) 
indicated that a reduction in fruit size after PCa application was related to increased fruit numbers and not a direct response to the PCa. It would appear that additional studies examining the effect of PCa on fruit set and fruit size are warranted.

Results from this study agree with earlier reports that demonstrated the growth controlling properties of PCa (Byers and Yoder, 1999; Byers et al., 2004b; Greene, 1999; Miller, 2002; Rademacher et al., 2004; Schupp et al., 2001). In five separate experiments over a period of 4 years, PCa consistently reduced terminal shoot length in 'Stayman 201' apple trees compared with the controls. No conclusions can be drawn from Expt. 1 concerning the effect of preharvest PCa sprays on terminal shoot growth because no preharvest PCa-only treatment was included in the study.

A combination of postbloom and preharvest PCa sprays (Expt. 1) reduced the growth of water sprouts produced near pruning cuts. Growth of water sprouts was unaffected when PCa was applied as postbloom sprays only followed by preharvest $\mathrm{GA}_{4+7}$ spray treatment. Schupp et al. (2003) reported that two PCa sprays applied soon after bloom in May had no effect on the growth of water sprouts produced on 'Empire' apple trees growing in New York or New Jersey. They concluded that PCa was applied too early to reduce the growth of water sprouts that are initiated after the first flush of terminal growth. The results in Expt. I illustrate the ability of PCa to control water sprout growth when applied in a combination of early (postbloom) plus late (preharvest) spray treatments. Unfortunately, this study did not include a postbloom-only or a preharvest-only PCa treatment, which may have provided some clarification as to the optimum timing of PCa for control of water sprout growth.

Regulaid was used as an adjuvant with PCa sprays in all experiments. When four other adjuvants, applied at the manufacturer's recommended rates, were compared with Regulaid (Expt. 5), there was no difference in the level of shoot growth control obtained among the adjuvants tested (Table 5). Byers et al. (2004b) reported that oil + Silwet $\mathrm{L} 77$ combined with PCa provided better shoot growth suppression on 'Fuji' apple trees than Regulaid, although the differences were small. In their study, three applications of PCa (as Apogee $27.5 \mathrm{DF}$ ) at $125 \mathrm{ppm}$ without an adjuvant reduced shoot growth compared with controls, but the level of growth reduction was enhanced when Regulaid or oil + Silwet L77 was added to the spray mixture. In the present study, the addition of any one of five different adjuvants did not increase growth suppression in 'Stayman 201' trees compared with trees sprayed with two PCa sprays alone. Other factors such as hard water can influence the growth response to $\mathrm{PCa}$ (Byers et al., 2004b; Schupp et al., 2003). In the present study, sprays were prepared using high calcium content well water; however, a water conditioner (AMS) was used in all sprays except those in Expt. 1. Both the 10\% and $27.5 \%$ formulations of PCa contain AMS, but the $10 \%$ material, which was used in Expt. 1, has a higher AMS content (90\% AMS) than the $27.5 \%$ formulation (56.1\% AMS) used in the remaining experiments. The results for growth control in Expt. 5 suggest that the choice of adjuvant is not as important as long as PCa sprays are applied to achieve good coverage and under conditions that support maximum absorption (slow drying and high relative humidity).

Gibberellins increase shoot growth through their effect on cell elongation (Métraux, 1987). Guak et al. (2001) reversed the growthretarding effect of $\mathrm{PCa}$ on apple when they applied $\mathrm{GA}_{4+7} \mathrm{I} \mathrm{d}$ after PCa treatment. Miller et al. (2002) reported that $\mathrm{GA}_{4+7}$ applied to apple trees in four sprays $(P F+10 d,+20 d$, $+30 \mathrm{~d}$, and $+40 \mathrm{~d}$ ) at $15 \mathrm{ppm}$ reduced the level of growth control obtained from two PCa sprays. Byers et al. (2004a) applied $\mathrm{GA}_{3}$ at 213 ppm as a tank mix with PCa in three sprays $(\mathrm{PF}, \mathrm{PF}+21 \mathrm{~d}$, and $\mathrm{PF}+53 \mathrm{~d})$ and reduced the growth suppression obtained with PCa alone. Miller et al. (2002) and Byers et al. (2004a) found no growth promotion from GA sprays alone, but Guak et al. (2001) reported growth of $\mathrm{GA}_{4+7^{-}}$ treated trees was greater than that of control trees. In studies previously mentioned, the GA material was applied at or near the time of the PCa application and just before the period of rapid growth in apple. In the present study, $\mathrm{GA}_{4+7}$ applied preharvest did not promote terminal shoot growth in any of the individual experiments except Expt. 6 (Table 6). In Expt. 3, the preharvest $\mathrm{GA}_{4+7}$ sprays partially reversed the growth suppression obtained with PCa applied postbloom as indicated by the significant interaction $(P=$ 0.0741 ) between $\mathrm{PCa}$ and $\mathrm{GA}_{4+7}$. $\mathrm{GA}_{4+7}$ alone did not affect the growth of water sprouts (Expt. 1). The lack of a postbloom PCa-only treatment in Expt. 1 prevents concluding that GA sprays interfered with the growthsuppressing activity of postbloom PCa treatment (Table 1 ).

Cracking of 'Stayman' apples varies from year to year, between sites, and sometimes even between trees on a given site (Byers and Carbaugh, 1995; Opara et al., 1997; Stiles et al., 1959; Verner, 1935). In this study, cracking varied from a low of $11.7 \%$ in 2001 to a high of $63.8 \%$ in the 1997 experiment. $\mathrm{GA}_{4+7}$, applied preharvest, beginning approximately 1 July in five biweekly sprays, reduced cracking in 'Stayman 201' apples an average of $52 \%$ compared with fruit on control trees in experiments from 1997 through 2001. Previous studies, which have demonstrated the effectiveness of $\mathrm{GA}_{4+7}$ for reducing 'Stayman' fruit cracking, have also shown that the level of control can vary (Byers et al., 1990; Unrath, 1991). In this study, there appeared to be no correlation between the level of cracking control achieved with $\mathrm{GA}_{4+7}$ and the natural level of cracking.

Postbloom applications of PCa increased in the percentage of cracked fruit in four experiments (Expts. 2, 3, 4, and 6). In Expt. 5, postbloom PCa increased cracking compared with untreated controls when an adjuvant was included with the PCa sprays. An adjuvant was included in all other experiments when PCa was applied. In Expt. 1, the percentage of cracked fruit was increased with a high-dose (250 ppm) postbloom PCa spray combined with multiple lowdose $(75 \mathrm{ppm})$ preharvest PCa sprays. Although the results of this study might suggest that the multiple postbloom high-dose [250 ppm (12 oz/ $100 \mathrm{gal})$ followed by $125 \mathrm{ppm}(6 \mathrm{oz} /$ $100 \mathrm{gal}$ )] treatments (Expts. 1, 3, 4, and 6) were responsible for increased fruit cracking, cracking was also 
increased with multiple low-dose [125 ppm $(6 \mathrm{oz} / 100 \mathrm{gal})$ followed by $63 \mathrm{ppm}(3 \mathrm{oz} / 100 \mathrm{gal})]$ postbloom sprays (Expt. 3 ). In the only published report involving PCa application on 'Stayman' apple trees, Byers and Yoder (1999) found no effect of a single application of PCa at 125,250 , or $375 \mathrm{ppm}$ on 'Stayman' cracking. $\mathrm{PCa}$ as a single-spray treatment was not applied in any of the experiments in this study because the author has observed over several years that single sprays result in unacceptable growth control in most apple cultivars growing under mid-Atlantic conditions compared with multiple sprays. Schupp et al. (2003) reported severe fruit cracking on 'Empire' apple treated with PCa in two of three trials in New York and New Jersey. They concluded that the injury was incited by PCa under certain environmental conditions. Fruit cracking in this study varied with year and specific treatment, but the majority of the evidence supports the hypothesis that $\mathrm{PCa}$ increases cracking in the 'Stayman' apple similar to its effect on Empire cracking as reported by Schupp et al. (2003).

When 'Stayman' apples were treated postbloom with $\mathrm{PCa}$ followed by preharvest sprays of $\mathrm{GA}_{4+7}$, the level of cracking was generally reduced, but not always (e.g., Expt. 4). Despite the ability of $\mathrm{GA}_{4+7}$ to reduce the level of fruit cracking in $\mathrm{PCa}$-treated trees, the reduction was not always to the same extent as that achieved by $\mathrm{GA}_{4+7}$ in non-PCa-treated trees. An example is Expt. 3 in which $\mathrm{GA}_{4+7}$ alone reduced fruit cracking from $48 \%$ to $19.4 \%$, a $60 \%$ reduction in the level of cracking. However, when trees were treated with a $12-\mathrm{oz} / 100$ gal spray followed by a $6-\mathrm{oz} / 100$ gal spray of $\mathrm{PCa}$, the preharvest $\mathrm{GA}_{4+7}$ treatment reduced cracking from $69.2 \%$ to $44.6 \%$, a reduction of only $36 \%$ in the level of cracking. A $44 \%$ level of cracking would be commercially unacceptable.

Byers et al. (1990) found that submerging 'Stayman' apples in a nonionic surfactant (adjuvant) solution increased cracking compared with a water-only submersion. They did not evaluate the effect of surfactant sprays alone on cracking in the field. In a later study, Byers et al. (2004b) increased cracking in 'Empire' apples compared with a control with three sprays of $\mathrm{PCa}$ $(27.5 \%$ formulation $)$ applied with AMS + Regulaid. A similar treatment with technical-grade $\mathrm{PCa} \quad(93.2 \%$ material) had no effect on cracking in 'Empire' apples. They attributed the increase in cracking to increased absorption of PCa. Schupp et al. (2003) exacerbated the cracking and corking damage they found on 'Empire' apples treated with $\mathrm{PCa}$ when they added AMS to the spray. When they applied AMS + Regulaid without PCa, they found little or no effect on the level or severity of fruit injury in 'Empire'. In the current study, two PCa (27.5\% formulation) sprays with AMS but without an adjuvant had no effect on fruit cracking $(P \leq 0.10)$. The addition any one of five different adjuvants increased the percentage of cracked fruit above the untreated controls with the greatest increase associated with Silwet L77 or DyneAmic, both organosilicone surfactants. These results suggest that AMS plus an adjuvant may increase absorption of $\mathrm{PCa}$ and the potential for fruit cracking in a cultivar prone to cracking such as 'Stayman'.

Results of this study clearly demonstrate the ability of PCa to suppress shoot growth in 'Stayman' apple trees. Two applications of $\mathrm{PCa}$ between $\mathrm{PF}$ and $\approx 4$ to 6 weeks after PF (postbloom period) were generally sufficient to reduce terminal shoot growth. Multiple preharvest applications of $\mathrm{GA}_{4+7}$ generally had no effect on shoot growth, but in some instances partially reversed the shoot growth-suppressing effect of PCa. $\mathrm{GA}_{4+7}$ spray treatments applied during the preharvest period generally reduced the incidence of fruit cracking; in PCa-treated and nonPCa-treated trees, however, the efficacy of $\mathrm{GA}_{4+7}$ to reduce cracking was clearly affected by postbloom PCa. Results from six experiments over 5 years demonstrated that PCa applied postbloom in 'Stayman 201' apples can increase the incidence of fruit cracking in this cultivar. Adjuvants, especially the organosilicone-based materials, may enhance uptake of $\mathrm{PCa}$ and lead to an increase in the level of cracking. Based on the results of these experiments, the use of $\mathrm{PCa}$ to control shoot growth on 'Stayman' apple trees should be approached with a great deal of caution because of the likelihood that fruit cracking will be increased, which may or may not be reversed by $\mathrm{GA}_{4+7}$.

\section{Literature cited}

BASF Corp. 2001. Apogee ${ }^{\circledR}$ plant growth regulator for use on apples and peanuts. BASF Corp., Research Triangle Park, NC.

Baugher, T.A., K.C. Elliott, and D.M. Glenn. 1995. Effect of sod competition and root pruning on 'Stayman' apple tree growth and fruit cracking. HortScience 30:222-226.

Beach, S.A., N.O. Booth, and O.M. Taylor. 1905. The apples of New York. New York Agr. Expt. Sta. Rpt. 1903.

Byers, R.E. and D.H. Carbaugh. 1995. Chemical, cultural, and physiological factors influencing 'Stayman' fruit cracking. Virginia Agr. Expt. Sta. Bul, 95-1.

Byers, R.E., D.H. Carbaugh, and L.D. Combs. 2004a. The influence of prohexadione-calcium sprays on apple tree growth, chemical fruit thinning, and return bloom. J. Amer. Pomol. Soc. 58:111-117.

Byers, R.E., D.H. Carbaugh, and L.D. Combs. 2004b. Prohexadione-calcium suppression of apple tree shoot growth as affected by spray additives. HortScience 39:115-119.

Byers, R.E., D.H. Carbaugh, and C.N. Presley. 1990. 'Stayman' fruit cracking as affected by surfactants, plant growth regulators and other chemicals. J. Amer. Soc. Hort. Sci. 115:405-411.

Byers, R.E. and K.S. Yoder. 1999. Prohexadione-calcium inhibits apple, but not peach tree growth, but has little influence on apple fruit thinning or quality. HortScience 34:1205-1209.

Costa, G., C. Giuliva, and A. Ramina. 1983. Influence of growth regulators on apple fruit cracking (cv 'Stayman Red'). Acta Hort. 137:367-374.

Dreiling, F.R. and G.R. Williams. 1962. Apple varieties for Virginia. Virginia Polytechnic State Univ. Ext. Serv. Circ. 849.

Evans, J.R., R.R. Evans, C.L. Regusci, and W. Rademacher. 1999. Mode of action, metabolism, and uptake of BAS $125 \mathrm{~W}$, prohexadione-calcium. HortScience 34:1200-1201.

Gardner, V.R. and E.G. Christ. 1953. Studies on cracking in Stayman apple. Hort. News 34:2701, 2710-2712.

Glenn, D.M. and S.S. Miller. 2005. Effects of Apogee on growth and wholecanopy photosynthesis in spur 'Delicious' apple trees. HortScience 40:397-400. 
Greene, D.W. 1999. Tree growth management and fruit quality of apple trees treated with prohexadione-calcium (BAS 125 ). HortScience 34:1209-1212.

Guak, S., D. Neilsen, and N.E. Looney. 2001. Growth, allocation of $\mathrm{N}$ and carbohydrates, and stomatal conductance of greenhouse grown apple treated with prohexadione-Ca and gibberellins. J. Hort. Sci. Biotechnol. 76:746-752.

Medjdoub, R., J. Val, and A. Blanco. 2005. Inhibition of vegetative growth in red apple cultivars using prohexadionecalcium. J. Hort. Sci. Biotechnol. 80:263-271.

Métraux, J.-P. 1987. Gibberellins and plant cell elongation, p. 296-317. In: P.J. Davies (ed.). Plant hormones and their role in plant growth and development. Martinus Nijhoff Publishers, Dordrecht, The Netherlands.

Miller, S.S. 1990. Stayman cracking: The problem and potential solutions. Mountaineer Grower 501:4-9.

Miller, S.S. 2002. Prohexadionecalcium controls vegetative shoot growth in apple. J. Tree Fruit Production $3: 11-28$.

Miller, S.S., G.M. Greene, II, and J.L. Norelli. 2002. Vegetative growth control and other effects from prohexadione- calcium (Apogee ${ }^{\circledR}$ ) in apple. Proc. Plant Growth Regulat. Soc. Amer. 29 $72-79$

Opara, L.U. 1996. Fruit cracking and splitting in apples Part III: Cracking the problem. Orchardist N.Z. 69:28-29.

Opara, L.U., C.J. Studman, and N.H Banks. 1997. Fruit skin splitting and cracking. Hort. Rev. (Amer. Soc. Hort. Sci.) 19:217-262.

Rademacher, W., J.B. Speakman, R.R. Evans, J.R. Evans, S. Roemmelt, S. Michalek, A. Lux-Endrich, D. Treutter, T. Iturriagagoitia-Bueno, and P. John. 1998. Prohexadione-Ca-A new plant growth regulator for apple with interesting biochemical features. Proc. 25th Plant Growth Regulat. Soc. Amer. p. 113-118.

Rademacher, W., K. van Saarloos, J.A Garuz Porte, F.R. Forcades, Y. Senechal, C. Andreotti, F. Spinelli, E. Sabatini, and G. Costa. 2004. Impact of prohexadione$\mathrm{Ca}$ on the vegetative and reproductive performance of apple and pear trees. European J. Hort. Sci. 69:221-228.

Schupp, J., T. Robinson, J. Norelli, D. Rosenberger, and H. Aldwinckle. 2001. Apogee: A new plant growth regulator for apples. New York Fruit Quarterly 9:19-21.

Schupp, J.R., T.L. Robinson, W.P. Cowgill, Jr., and J.M. Compton. 2003. Effect of water conditioners and surfactants on vegetative growth control and fruit cracking of 'Empire' apple caused by prohexadione-calcium. HortScience 38:1205-1209.

Stiles, W.C., N.F. Childers, M.Z.J. Prusik, and T.N. Kom. 1959. Effects of urea sprays and pesticides on russeting and cracking of Stayman apple. Proc. Amer. Soc. Hort. Sci. 74:25-29.

Sullivan, D.T. and F.B. Widmoyer. 1970. The effect of Altar (sic) on fruit cracking of Stayman Winesap apple. Fruit Var. Hort. Dig. 24:17-18.

Sutton, T.B. and C.R. Unrath. 1984. Evaluation of the tree-row-volume concept with density adjustments in relation to spray deposits in apple orchards. Plant Dis. 68:480-484.

Unrath, C.R. 1991. The influence of concentration, spray interval and number of applications of $\mathrm{GA}_{4+7}$ (Provide) on suppression of 'Stayman' fruit cracking. HortScience 26:688. (Abstr).

Valent BioSciences Corp. 2005. ProVide ${ }^{\circledR}$ $10 \mathrm{SG}$ plant growth regulator water soluble granules. Valent U.S.A. Corp, Walnut Creek, CA.

Verner, L. 1935. A physiological study of cracking in 'Stayman Winesap' apples. J. Agr. Res. 51:191-222. 